\title{
The impact of Christian Higher Education on the lives of students and societies in Africa
}

\begin{tabular}{|c|c|}
\hline $\begin{array}{l}\text { Author: } \\
\text { Petria M. The }\end{array}$ & $\mathrm{on}^{1}$ \\
\hline $\begin{array}{l}\text { Affiliation: } \\
{ }^{1} \text { School of Ecc } \\
\text { Sciences, Nor } \\
\text { University, Po } \\
\text { Campus, Sout }\end{array}$ & $\begin{array}{l}\text { esiastical } \\
\text { h-West } \\
\text { chefstroom } \\
\text { Africa }\end{array}$ \\
\hline $\begin{array}{l}\text { Corresponde } \\
\text { Petria Theron }\end{array}$ & ce to: \\
\hline $\begin{array}{l}\text { Email: } \\
\text { petria.theron }\end{array}$ & @nwu.ac.za \\
\hline $\begin{array}{l}\text { Postal addres } \\
68 \text { Molen Stre } \\
\text { Potchefstroon } \\
\text { South Africa }\end{array}$ & $\begin{array}{l}\text { : } \\
\text { et, } \\
2520 \text {, }\end{array}$ \\
\hline $\begin{array}{l}\text { Dates: } \\
\text { Received: } 09 \\
\text { Accepted: } 12 \\
\text { Published: } 15\end{array}$ & $\begin{array}{l}\text { uly } 2012 \\
\text { Vov. } 2012 \\
\text { Apr. } 2013\end{array}$ \\
\hline $\begin{array}{l}\text { How to cite t } \\
\text { Theron, P.M., } \\
\text { impact of Chr } \\
\text { Education on } \\
\text { students and } \\
\text { Africa', Koers } \\
\text { Christian Sch } \\
\text { Art. \#60, } 8 \text { pa } \\
\text { http://dx.doi. } \\
\text { koers.v78i1.6 }\end{array}$ & $\begin{array}{l}\text { is article: } \\
\text { 2013, 'The } \\
\text { stian Higher } \\
\text { he lives of } \\
\text { ocieties in } \\
\text { - Bulletin for } \\
\text { larship 78(1), } \\
\text { ses. } \\
\text { rg/10.4102/ }\end{array}$ \\
\hline $\begin{array}{l}\text { Note: } \\
\text { This article w } \\
\text { as a paper at } \\
\text { Conference o } \\
\text { Societies in th } \\
\text { Religion and } \\
18-22 \text { June } 2 \\
\text { Pietermaritzb } \\
\text { the University } \\
\text { Natal, South }\end{array}$ & $\begin{array}{l}\text { s delivered } \\
\text { The Joint } \\
\text { Academic } \\
\text { e Fields of } \\
\text { heology,' } \\
12 \text {, } \\
\text { urg Campus of } \\
\text { of KwaZulu } \\
\text { frica. }\end{array}$ \\
\hline $\begin{array}{l}\text { Copyright: } \\
\text { (C) 2013. The } \\
\text { Licensee: AOS } \\
\text { OpenJournals } \\
\text { is licensed un } \\
\text { Creative Com } \\
\text { Attribution Lic }\end{array}$ & $\begin{array}{l}\text { uthors. } \\
\text { IS } \\
\text { This work } \\
\text { ler the } \\
\text { nons } \\
\text { ense. }\end{array}$ \\
\hline Read online: & \\
\hline 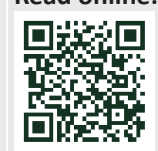 & $\begin{array}{l}\text { Scan this QR } \\
\text { code with your } \\
\text { smart phone or } \\
\text { mobile device } \\
\text { to read online. }\end{array}$ \\
\hline
\end{tabular}

Corruption is a worldwide problem. Authors do not only agree that it should be addressed at a personal level, but they encourage everyone to become involved in the fight against corruption. For this to happen, individual transformation is a prerequisite. In this article, Chipapata, Fátima and Jacinto's personal stories will bear witness to the potential role of Christian Higher Education (CHE) in the moral and spiritual transformation of individuals in local African communities. These three persons were extra-mural students enrolled at Hefsiba in Mozambique. That the impact of these three persons' studies goes beyond the personal level is seen in the community in which they live and work. They consented to tell their stories starting with events before they commenced their studies, sharing experiences they had during their studies and describing how their studies impacted their lives, families, work and the community in which they live. In this article, the essence, purpose and content of CHE are addressed. It is argued that through CHE, students' faith and education could be integrated. Apart from being competent in their professions, students would be committed to apply their competency to deal with the spiritual and material conditions of their communities. This might bring about a transformation of society.

Die impak van Christelike Hoër Onderwys op die lewens van studente en gemeenskappe in Afrika. Korrupsie is 'n wêreldwye probleem. Outeurs stem nie net saam dat dit op persoonlike vlak aangespreek moet word nie, maar hulle moedig almal ook aan om betrokke te raak in die stryd teen korrupsie. Dit kan net gebeur as individuele transformasie reeds plaasgevind het. In hierdie artikel lewer Chipapata, Fátima en Jacinto se persoonlike verhale getuienis van die potensiële waarde van Christelike Hoër Onderwys $(\mathrm{CHO})$ met betrekking tot die morele en geestelike transformasie van individue in plaaslike Afrikagemeenskappe. Hierdie drie persone was buitemuurse studente van Hefsiba in Mosambiek. Die impak van hierdie drie persone se studies strek verder as bloot hul persoonlike lewens. Dit is ook sigbaar in die gemeenskap waarin hulle woon en werk. Hulle het ingestem om hul verhale te vertel, beginnende by gebeure voor die aanvang van hul studies, hul ervarings tydens hul studies en hoe hul studies hul lewens, gesinne, werk en gemeenskap beïnvloed het. In hierdie artikel word die essensie, doel en inhoud van $\mathrm{CHO}$ aangespreek. Daar word geargumenteer dat studente se geloof en onderwys geïntegreer word deur CHO. Studente word dus nie net toegerus vir hul professies nie, maar behoort ook toegewyd te wees om konstruktief by die spirituele en materiële nood van hul gemeenskappe betrokke te raak. Dit mag moontlik 'n transformasie van die gemeenskap tot gevolg hê.

\section{Introduction}

The month of February is traditionally of utmost importance to South Africans, as the President of the Republic opens the activities of parliament with his or her state of the nation address. Shortly after that, the budget speech by the Minister of Finance follows. During the days before these important speeches, there usually are some emotional debates in the media regarding the political and financial scenario of the country. The beginning of 2012 was no exception. It was during this time that South Africans were reminded of the words of Willie Hofmeyr, the former Head of the Special Investigating Unit, to the Parliament Portfolio Committee on Justice in 2011. He stated that $20 \%$ of the procurement budget might be lost to corruption annually. This amounts to a shocking R25 billion - R30 billion a year (O'Regan 2012:6). Events all over the world show that corruption is not only a problem of the African continent. On 17 February 2012, the President of Germany resigned because of allegations of corruption (Pidd 2012). Legal sanctions will probably never adequately deter people from getting involved in corruption. According to Bull and Newell (2003:244-245), corruption should be addressed at another level, viz. that of personal honesty. The title of O'Regan's article, 'Stamping out corruption is everybody's business', conveys a similar message (O'Regan 2012:6). The challenge is to achieve this ideal at grass roots level. In 
order to bring about change in society, ordinary citizens as well as leaders should be committed and equipped to live and work according to high standards of personal honesty and integrity. The starting point is transformation at an individual level. Following the old saying that prevention is better than cure, this transformation should start at a young age. Therefore, I propose that the focus should be on young people as leaders of the future.

The question is how Christian Higher Education (CHE) can contribute to the moral formation of young leaders in societies where corruption and immorality are endemic. My hypothesis in this article is that CHE could contribute not only to the general acquisition of knowledge, but also to the moral formation of students in particular. Consequently, it could contribute to the transformation of the societies in which they will eventually live and work, as will be illustrated by the narratives of the three students from Mozambique.

In this article, by implementing the qualitative research methodology of participatory action research, three students from a CHE institute in Mozambique share their experiences. Reason and Bradbury $(2008: 1,4)$ mention that participatory action research aims to engage those who would otherwise be largely the research subjects, as inquiring co-researchers. This method of research draws on the knowledge and experiences of the participants in the pursuit of practical solutions to pressing issues of individuals and communities. A relatively new methodology within this field is autoethnography. Labuschagne (2008:vi-vii) explains that the word consists of three parts, namely, (1) auto [self], (2) ethnos [culture] and (3) grapho [to write]. An auto-ethnographical study allows reflection on ordinary aspects of society, people, relationships and the self. It connects the person who is writing his or her story with the culture around him or her. In this manner, the self and lived experiences are incorporated to enrich the research. Brunsdon and Lotter (2011) refer to the value of auto-ethnography in the field of qualitative research, where the participant gets the opportunity to write about his or her personal experiences within a particular situation. In this way, much could be learned from the selfnarratives. Following the empirical section, I will focus on CHE in general, and on CHE in Sub-Saharan Africa in more detail. To conclude this article, I will make some preliminary suggestions regarding the content of a curriculum that could promote spiritual and moral transformation of students, and that could consequently have a positive impact on the communities in which they live.

\section{Narratives from Mozambique}

I will give a short history of Hefsiba Instituto Superior Cristão (Hefsiba ISC). Then three alumni will tell their stories, focussing on events during the time before they commenced their studies, their experiences during their studies and how their studies have impacted their lives, families, work and the community in which they live. They have consented that their names and an abbreviated, translated version of their narratives may be used in this article. The study was done in accordance with the ethical guidelines set by the North-West University (n.d. [a, b]) Chipapata, a 40 year old male, Fátima, a 40 year old female and Jacinto, a 45 year old male, were part of the first group of evening students who started their studies in 2006. Chipapata, a secondary school teacher, enrolled at the Faculty of Theology, whilst Fátima, who works at the local telecommunications company, and Jacinto, a journalist from Tete, enrolled at the Faculty of Psychology. A short discussion will conclude the empirical section of the article.

\section{Hefsiba Instituto Superior Cristão}

Mozambique was involved in a liberation war with Portugal from 1964 to 1974. Two years after independence, in 1977, a civil war broke out between Frelimo and Renamo. The peace accord was signed in October 1992, after 15 years of bloodshed and destruction. It was during this time that the leaders of the Igreja Reformada em Moçambique ${ }^{1}$ realised that there was no possibility of tertiary education in the northwestern part of Mozambique. Their dream was to start a tertiary education facility at Vila Ulónguè, which was realised in 1994. Initially, Hefsiba only provided theological training to students who wanted to become pastors in a variety of Christian church denominations. The students, together with their families, stayed on the premises. Whilst the men received theological training, the wives received basic training to prepare them for their ministry as pastors' wives. Their small children attended a crèche and a preschool, and the older children were enrolled at the local primary and secondary schools. In 1996, the Potchefstroom University for Christian Higher Education (PU for CHE) accredited their Theological School's program. In 2004, the school received accreditation from the Mozambican Government and became Hefsiba ISC, an autonomous institute for $\mathrm{CHE}$ with one faculty, that of Theology. The need for tertiary education was so overwhelming that a second faculty, the Faculty of Psychology, was started in 2006. The goal was to provide a wider spectrum of people, and not only future pastors, with the opportunity to receive tertiary education that would culminate at the level of bachelor's degree. In 2009, Hefsiba ISC received permission from the Mozambican government to confer honours degrees in Theology and in Psychology. The influence of Hefsiba ISC is spreading further, as lecturers from Angolan tertiary institutions, who are not accredited by their government, are enrolling as students at Hefsiba ISC for further studies. The Mozambican government also approved the curriculum of the Faculty of Economics and Business Administration in 2011, and the first group of these students enrolled in February 2012. The three students' narratives, which will follow now, are the histories of their lives and are therefore written in the first person.

\section{Chipapata's narrative}

'I was born in 1973 and raised in a Christian home. Our family regularly attended the Evangelical Assemblies of God Church. I was part of the youth group and conducted 1.The English translation is Reformed Church in Mozambique. 
the youth choir. My father was my role model. We held regular family devotions. I recall how my heart was moved by passages like Exodus 20:12, where young people are instructed to honour their parents. These passages motivated me to be obedient to my parents and contributed significantly to my moral and spiritual formation.

In 1990, when I was 17 years old, our village was attacked and I was recruited to become a soldier. Military life caused me to abandon any form of religion and I denied God as my Saviour. In an attempt to gain courage and to quiet the feelings of fear, I started using drugs, which included smoking and drinking. I was quickly addicted to these substances. When the war ended, I enrolled at a teachers' training college. On completing my training in 1995, I was transferred to Vila Ulónguè. I continued to struggle with my addiction and regularly visited witch-doctors, from whom I sought help to stop the drinking and smoking, but to no avail. Later, with a lot of self-discipline, I managed to stop smoking, but I could not free myself from the alcohol. My reputation as a teacher was ruined because of my drinking, which gave me a false impression of my intellectual capability. In reality, I was not even able to manage my finances and ended up with a lot of debt.

In 2006, I enrolled at Hefsiba and, with the power of the Lord, the support and encouragement of my fellow-students and lecturers, I managed to overcome my addiction. It was difficult, because for years I had not been able to do anything without first taking a drink. The moment I was free from the power of alcohol, I could notice the positive effect it had on my life, my family, on the Christian community and on my performance at work. ${ }^{2}$ In 2011, I finished my Honours Degree in Theology and I am currently enrolled for the Master's Degree in Biblical Interpretation at a Christian university in Portugal.'

\section{Fátima's narrative}

'I grew up in a Roman Catholic family. We regularly attended mass and I belonged to the choir. I have fond memories of my family, but because of the war, it was a difficult time to grow up. We often had to flee and spend nights in the bush. I saw many people seriously wounded and killed. When I grew older, I went to a boarding school. We could attend church on Sundays, but no other church activities.

My husband was a wonderful man and we had a good relationship, but when we lost our first-born in 1991, our 4 year old son in 1998 and our baby daughter in 2003, my husband changed. He started to drink alcohol and peace left our home. I tried to teach our kids the correct way of living, but we were not good examples. We didn't attend church anymore and we often visited the witch-doctor to see if he could discover the cause of our misfortune. Our family disintegrated and our children preferred to stay with their grandparents.

2.Chipapata was notorious for his drinking habits. Because of the positive changes in his life, the Director of Education at district level requested Hefsiba ISC to consider offering a two-year Education Diploma, which had to be designed for teachers who could not enrol at Hefsiba for graduate studies.
One day my husband came home, drunk as usual, and said that we must enrol for further studies at Hefsiba. I told him that it is a Christian institution and that they would not permit an alcoholic to enrol. He said he would quit drinking, and during the interview, he repeated his commitment. We were accepted as students and experienced unconditional acceptance from our fellow-students and lecturers. Our classes always started with devotions. We received Bibles and started to read them. Because we were biblically illiterate, we could not pray and did not know God. In time, I got to know God as a loving Father, who wants the best for his children, who is in control and who leads his children on the right way, if only they would heed his voice. We learned so much and it helped us to overcome our pain and difficulties. Things changed and in our second year, our children were re-united with us. They were overjoyed to see the change in us.

Our neighbours similarly noticed the changes in our lives, especially the way my husband helped me with domestic chores - something very uncommon in Mozambique. His "drinking colleagues" were upset at losing their friend, but he convinced them to also enrol at Hefsiba, and they experienced similar changes through Christian education based on biblical principles. My professional life changed dramatically - I have patience with my clients, good relationships with my colleagues and as a result of the improvement in my work, I was promoted. Today, people come to me for Christian counselling.

I see differences in Vila Ulónguè as a result of Hefsiba. Previously, it would be very rare for a community leader to speak at a public meeting about God or quote a passage from Scripture, but today it is common practice as more and more community leaders are studying at Hefsiba. I am convinced that if Africa chooses for $\mathrm{CHE}$, the development will be much quicker, because people will understand the principle of love for God and love for their neighbour, as I had to learn it. Once people understand the essence of love, leaders will be less egoistic and corrupt and will consider others in the community and not only their personal gain. I will make every effort to ensure that our children will receive $\mathrm{CHE}$, because it is the only education that moulds a person in totality.'

\section{Jacinto's narrative}

'I have good memories of my childhood. Life was easy and my parents provided everything I needed. We regularly attended the Roman Catholic Church. My parents nurtured in me a desire to go to school and to study. My father was a loving husband and a good example to us as a family. My parents would often get the kids together and talked to us about important things in life. Our family once went through a difficult time. My father lost his job as manager at his company. He started to drink, but my mother, a strong woman, took control and we managed to overcome difficulties without serious consequences to our family. 
When I left home, I got involved with the wrong friends, got enticed into bad habits and no longer went to church. I met my future wife while we were students. I chose her because she was committed to her church (Jehovah Witnesses) and I thought that would ensure a happy marriage. In order to win her affection, I had to behave extremely well and could not afford to make a mistake. We got married and had a good relationship, except for the fact that she could not communicate her feelings well.

When I started my studies at Hefsiba, I found the prayer at the beginning of every class very strange, although it meant a lot to me - I was going through difficult times and needed prayer. We had many conversations in the class and I often got angry with my fellow-students, because I experienced them as being judgemental. Later I realised that those conversations helped me to overcome my bad habits ${ }^{3}$. I learnt a lot and this had a positive influence on my relationship with my wife. Because of the changes in my life, she also wanted to study at Hefsiba. We would solve our conflicts in constructive ways and our children are happy and confide their problems. As a family, we support and encourage each other. Other couples notice the change and often ask for advice.

As a result of my academic training and the way I changed, I got a new job and I am looking forward to it, as it will offer many opportunities to apply my training as a counsellor. I will be able to make a difference in the community. The positive changes in my fellow-students' lives and in Vila Ulónguè are evident because of the education offered at Hefsiba. Many leaders in the community are studying there and they are starting to practice what they preach. Fundamentally, I believe that $\mathrm{CHE}$ can have a similar impact in communities throughout Africa. My wife and I will do our best to see that our children also receive $\mathrm{CHE}$, because it transforms persons and communities.'

\section{Discussion}

The majority of the students enrolled at Hefsiba do not come from a reformed ${ }^{4}$ Christian background ${ }^{5}$. According to the three alumni interviewed, students often lack knowledge of the Bible and often do not know how to pray. For many the devotions and prayer at the beginning of the classes are very strange. As could be seen in the narratives, some of them are antagonistic towards the idea initially, but they appreciate it later on. Many of the students get to know the Lord Jesus Christ relationally for the first time, whilst others renew their commitment to him. The students value the support, encouragement and unconditional acceptance of their fellow-students and lecturers. In the classes, the students and the lecturer would often have lively discussions about the content of the studies, evaluating it in the light of

3.Jacinto also had a drinking problem.

4.The character of the reformed theology can be summarised by five Latin expressions, namely sola deo gloria [glory to God alone] sola gratia [grace alone] solus Christus [Christ alone], sola scriptura [by scripture alone] and sola fide [by faith alone] (Vorster 2010:432).

5.This is confirmed by the information on the students' admission forms. biblical principles. These conversations would sometimes continue after classes and this helped students to apply newly acquired knowledge to their own lives. It brought about a new mindset as a Christian worldview began to form in their thinking. Consequently, they start to think and live differently, which impacts their families, professional lives and communities. Being able to speak about a Christian way of life is significant, as most of the students are community leaders. Sometimes, they even refer to God or quote a passage from Scripture at public meetings, something unheard of in a former communist country. It is important to take notice of the students' comments regarding the value of CHE. They want their children to receive CHE, because - according to them - it moulds the student as a total person and benefits the community. Two students refer to the benefits Africa could gain from this kind of education. When leaders understand the essence of love and respect the dignity of all people, they will be less egoistic and corrupt.

\section{Christian Higher Education}

Many changes accompanied the establishment of a democratic dispensation in South Africa in 1994. Amendments in the national education structure after 1998 necessitated the amalgamation of tertiary educational institutions in all provinces. One of the consequences of the amalgamation process was name changes. In the North-West Province, the former Potchefstroom University for Christian Higher Education (PU for $\mathrm{CHE}^{6}$ ) became the Potchefstroom Campus of the North-West University (NWU) in 2003. During negotiations regarding the name change, it became clear that it was politically impossible to keep the ' $\mathrm{CHE}^{\prime}$ component in the name of the new university. The historical motto of the university 'In Your light' also disappeared (Eloff 2003:1-2; Van Eeden 2006b:113, 132-133). With the establishment of the NWU, it was written into its mission statement that it would be a value-driven institution, and students and lecturers would be allowed to continue to live up to their Christian principles and a Christian perspective on science (Eloff 2003:2). From the short history of the NWU, it is clear that although the ' $\mathrm{CHE}^{\prime}$ has disappeared from the name of the university, it is still present in the educational endeavour. I am convinced that Christian higher education may still be considered a viable option, even in a secular age.

In this section, I will give a historical overview of $\mathrm{CHE}$ and propose a biblical foundation for $\mathrm{CHE}$, including the purpose of CHE and the work of the International Association for the Promotion of Christian Higher Education (IAPCHE). IAPCHE can be considered as the global champion of CHE. I will conclude by focussing on $\mathrm{CHE}$ as a worldwide movement and on its impact in Africa, especially Sub-Saharan Africa.

6.The Education Act nr. 19 of 1950 of the Republic of South Africa made provision that the university could uphold its Christian character. Under Christian scholarship was the university could uphold its Christian character. Under Christian scholarship was understood that God is in control of everything and that science should therefore be at the service of God and be practised to his honour (Van Eeden 2006a:502-503). The university implemented Christian scholarship by means of the compulsory subject 'Philosophy of Science' (Afrikaans: Wetenskapsleer) and through the efforts of lecturers who taught their disciplines from a Christian perspective (Van Eeden 2006b:125-127). 


\section{Historical overview and biblical foundation}

In 1898, the Dutch theologian Abraham Kuyper ${ }^{7}$ delivered his famous Stone lectures at Princeton University, where he spoke on Calvinism as a worldview. He did not refer to Calvinism as a particular theology, but as a central Christian conviction that everything belongs to Christ, including the entire universe and all aspects of life (Holmes 2001:104). Hence his famous statement, "There is not a square inch in the whole domain of our human existence over which Christ, who is sovereign over all, does not cry: "Mine!"' Accordingly, humankind received its cultural mandate when God told the first persons to take care of creation and to develop it further, as found in the passages of Genesis 1:28 and Genesis 2:15 (Van der Walt 2010a:115). When God gives humans the responsibility to subject and rule over creation, it is not in the sense of ownership, but in the sense of stewardship, namely to manage creation for God, its real owner (Walton 2001:141). The Lordship of Jesus Christ, alluded to by the Kuyperian-reformational worldview, forms the foundation of CHE and poses the challenge to Christian academics to develop and exhibit a Christian perspective as an integral approach to all subjects in a curriculum (Hulst 1992:4; Van der Walt 2008a:107; Van der Walt 2010a:113). The motto of the former PU for CHE, 'In Your light,' is found in Psalm 36:9 and conveys the idea of Christian scholarship, in other words that science should be practised 'in God's light'. All academic and administrative activities at the university were geared to express a Christian reformational perspective (De Klerk 2003:312-313).

A higher institution, argues Coletto (2010:9), is not 'Christian' when the lecturers are Christians, or when the institution is controlled by a church denomination, or when some 'religious' courses are added to the 'normal' list of courses. The Kuyperian reformational approach stresses the importance of the content of the curriculum. Sound Christian education is possible when subjects are taught and practised in the light of the Word of God and when the Bible modifies the content. This approach corresponds with IAPCHE's statement regarding the foundation of $\mathrm{CHE}$ at the break of the new millennium: the task of $\mathrm{CHE}$ should be performed in the light of God's inscripturated revelation, and God's Word and Spirit should structure and guide created reality (Hulst 2008:32). The passage in Scripture where the apostle Paul writes, 'We demolish arguments and every pretension that sets itself up against the knowledge of God, and we take captive every thought to make it obedient to Christ' (2 Cor 10:5), demonstrates the three responsibilities of Christians in higher education well, according to Van der Walt (2010a:125). The first part of the passage shows the antithesis, the second part refers to the action of integration and the last part mentions the act of transformation. For Kuyper, Christianity is not only about personal conversion, but it must have an impact on society. Therefore, if Christian principles are not permitted in

7.The Dutch Calvinist, Abraham Kuyper, is widely recognised as historian, theologian, philosopher, writer, professor-educator, and statesman. He championed the recognition philosopher, writer, professor-educator, and statesman. He championed the recognition of private education (common and higher) by government. As a result of the work of Kuyper and others, the Amsterdam Free University was opened on 20 October 1880, dedicated to a Calvinistic orientation. In 1886 he led the break from the State Church and the Reformed Churches in the Netherlands were established with Kampen as its seminary (Christian Classics Ethereal Library n.d.). the public square, Christians have to start private institutions based on a reformational worldview to assist students in building a bridge between their faith and their daily lives. As higher education would then be at the service of God, it could transform society (Van der Walt 2010a:117). By starting private institutions, Christians should be careful not to isolate them from the world, because they have the calling to be 'the salt and light of the world' (Mt 5:13-16).

In 1975, the International Association for the Promotion of Christian Higher Education (IAPCHE) was founded at the PU for CHE with the aim to promote the development of integral CHE worldwide, so that academic work could be pursued from a biblical, holistic perspective and worldview (Hulst 2002:119; Van der Walt 2008b:190). In a recent publication, Jochemsen (2011:1) formulated the objective of IAPCHE as follows: 'to equip Christians in higher education to live, think and act in a Christian way as academics and/or professionals.' This means that Christian students should be taught to become Christian professionals in a postmodern pluralistic society. The intrinsic value of $\mathrm{CHE}$, says Nguru (2008:143), is that it helps a student to become a certain kind of person and to do certain kinds of things. Students' faith and education should be integrated in such a way that students would be competent in their profession, but also committed to apply their competency to address the spiritual and material conditions of the African continent and the world. The aim of CHE institutions as described by Nguru corresponds with the four tasks of CHE as stated in the declaration of IAPCHE in 2000 (cf. Hulst 2008:32). Firstly, it wants to deepen students' understanding of the world and human life in it. Secondly, it wants to address and correct distortions in all of life. Thirdly, the aim is to prepare students through knowledgeable and competent discipleship for a complex world. Finally, it endeavours to serve the larger Christian community, as it seeks to bring Christ's healing to all areas of life.

\section{Christian Higher Education globally}

Today, CHE institutions and representatives of the Christian reformational philosophy and scholarship can be found in countries all over the world, for example in the Netherlands, South Africa, the USA, Canada, Australia, New Zealand, England and South Korea (Van der Walt 2010a:122, 128). Furthermore, $\mathrm{CHE}$ has become a growing movement. During the last 30 years, at least 178 new Christian universities were established worldwide (Carpenter 2012:1). Going hand in hand with globalisation, there is an increasing need for more highly educated people, because it is recognised that higher education could improve the chances of personal and communal advancement. Many governments, being unable to meet this need, have opened the way for universities that are independently organised. Christian groups are making avail of the opportunity (Carpenter 2008:339-340). Scholars mention the change that has occurred in global Christianity in recent years, namely a movement away from primarily Northern and Western faith to a predominantly Southern one. The centre of gravity in the Christian world has shifted away from Europe and America to Africa, Asia and Latin 
America (Hittenberger 2004:184; Carpenter 2008:344; Vorster 2012). This movement opens up enormous opportunities for educational institutions.

\section{Christian Higher Education in Africa, especially in Sub-Saharan Africa}

Van der Walt (2010a:129) is of the opinion that there is currently a greater need for Christian universities than theological schools in Africa. One way to address this need is that existing theological schools could broaden their sphere of influence by further growth and by developing other faculties. Hittenberger (2004:192-193) shows that CHE is not a new phenomenon in Africa. Already during the 4th century, one of the famous early church fathers, Augustine of Hippo (AD 354-430), lived and taught in the university town of Carthage (O'Donnell 2012). This is an illustration of the truth of the Latin proverb Semper aliquid novi Africa affert [Africa is always producing some novelty], which was formulated by the Roman author Pliny (Van den Heever 2012).

Colonialism and the Western Christian missionary movement in the 19th century led to the establishment of primary and secondary education, and later higher education on the African continent, especially in Anglophone and Francophone countries. In the 1950s, the African independence movement gained momentum and African governments sought to nationalise and expand tertiary education. During this time, Christian theological training institutions and Bible schools continued to be established. Daystar University in Kenya was one of the first CHE institutions to be established (1964) in postindependence Africa. On their website, their mission statement reads:

Daystar University seeks to develop managers, professionals, researchers and scholars to be effective, Christian servantleaders through the integration of Christian faith and holistic learning for the transformation of church and society in Africa and the world. (Daystar University 2012)

After the 1980s, African universities started to multiply (Hittenberger 2004:193). Of the 178 new Christian universities mentioned earlier, 46 are on the African continent (Carpenter 2012:1). The problem is that private universities remain small and that they can only accommodate a small number of the students who qualify for tertiary education. The Centre for the Promotion of CHE in Africa $\left(\mathrm{CPCHEA}^{8}\right)$ has been established recently. The hope is cherished that it will provide the necessary leadership on the African continent to ensure inter alia academic quality and relevant curriculums in CHE institutions. The aim is that these institutions would produce Christian leaders who could transform their societies and bring hope to the African continent (Nguru 2008:137-139). The founding head of the Central University College in Accra, Ghana, communicates a similar message, namely that the college was started in an effort to solve the crisis of leadership in order to enhance the African renaissance. It is clear that $\mathrm{CHE}$ institutions envisage service to the broader society (Carpenter 2008:340).

8.CPCHEA is doing the same work as IAPCHE, but only in Africa. The two organisation are closely affiliated.

\section{Educational, moral and spiritual formation of students}

At Hefsiba ISC, some students got to know the Lord Jesus Christ for the first time, whilst others renewed their commitment to him. The majority of the students, however, lacked spiritual knowledge and the life-skills to live up to a Christian life. I thus agree with Chaplin (2011:24) and De Muynck, Hegeman and Vos (2011:5-7) that CHE has the task of preparing students to be authentic Christians in a secularised ${ }^{9}$ world. From the narratives of the three students, it is clear that because of their education at a Christian higher institute, they started to think and live differently. They experienced the impact of CHE on their lives, their families, their professional lives and their communities. That is exactly what Nguru (2008:147) envisages - that Christians should participate actively in the economic, political and social development of their countries in order to overcome the present crisis in Africa. Spiritual and moral formation is therefore necessary for students to bridge the gap between their faith and their professional practice with integrity. To achieve this, I am of the opinion that two aspects are of utmost importance during their educational formation. Firstly, careful attention should be given to the content of the curriculum, and secondly, the methodology of the educational endeavour is of utmost importance.

\section{Content of the curriculum}

At Hefsiba ISC, a deliberate effort is made to write and evaluate a curriculum according to the following principles:

- it should be value-driven according to reformed principles

- it should reflect a holistic and integrated, but also inclusive approach

- it should be written according to outcome-based principles where the affective outcome should be prominent

- it should be missional in nature and contextualised within the Sub-Saharan African and more specifically the Mozambican context

- it should comply with high academic standards with emphasis on the enhancement and development of higher thinking skills (Du Preez 2012).

Although the curriculum was developed from a reformed Christian perspective, it is not a prerequisite that applicants should be Christians.

\section{Christian ethics}

Lategan (2003:363-366) is of the opinion that Christian ethics should be included in the curricula of all scientific disciplines at a higher education level. As the future employees and employers in all spheres of society, students must be equipped to face the ethical challenges posed by their future careers. They must be enabled to make decisions based on principles and values in order to ensure normative and value-driven behaviour. According to Vorster (2007:20), the basis of Christian ethics is found in the attitude of Christ, namely an attitude characterised by love, stewardship, selfdenial and obedience to God (cf. Phlp 2:5-11). This attitude

9.Followers of secularism believe that the foundations of the state are secular and religion is far removed from it. The consequence is that they attempt to eradicate all religious influences from society (Holthaus 2011:42). 
should guide people in their relationships and activities. Then students will be responsible and influential citizens. At Hefsiba ISC, Christian ethics is one of the core subjects in the curriculum of the existing three faculties.

\section{Christian values}

The moral formation of a student implies the development of his or her moral character. It is primarily a preventative pedagogical task and not a curative obligation. Moral formation does not only address the cognitive and rational development of a person, but also his or her personal attitudes, skills, moral passions and emotions. Therefore, a virtue-ethical approach to moral formation suffices, as it ensures the moral formation of the person and the formation of the person in social and political life (Vos 2011:143-144). I prefer 'Christian values' instead of 'virtues', as both cause people to conduct themselves in a certain way. Values and virtues influence and determine peoples' actions and choices (cf. Vos 2011:145-146). At Hefsiba, the management and lecturers identified seven core values that serve as guidelines for all academic and other activities, viz. loyalty, honesty, responsibility, compassion, justice, respect and quality. It is envisioned that students could internalise these values and that they could live and work according to them. Referring to the narratives of the three students at the beginning of the article, it is apparent that the vision became a reality in the students' lives. Their lives were changed, which had an impact on many other peoples' lives around them.

\section{Christian worldview}

Hegeman and Jochemsen (2011:99) affirm the role of worldviews in the process of moral formation, because worldviews form a person's beliefs, which in turn regulate performance in practice. Students need to learn to think and to live in a coherent way and according to Garber (1996:111-112), their worldview is instrumental in this process of integration. Students also need lectures that incarnate this integrated worldview. Van der Walt (2010b:2) and Blokhuis (2011:109-110) explain that a Christian worldview is usually seen as an elaboration of the meaning of the Christian faith for a vision of reality and human life. A person's worldview is thus a framework of beliefs about things. It is not only relevant for one's personal life, but also for the whole of life, including marriage, family, business, education and professional life. It helps him or her to understand the relationship between faith and science, and faith and practice. A worldview gives, by way of definition, a particular perspective on theology, philosophy, ethics, biology, psychology, sociology, law, politics, economics and history (Noebel 2001:2). It is by means of an integral Christian worldview that believers are orientated to influence the unbelieving world around them, and to live up to their calling and responsibility to make the world a better place in all areas of life. A Christian worldview helps Christians to understand that they are in full-time service of God, independent of their profession (Theron \& Lotter 2009:487-488). In their training, says Blokhuis (2011:112-115), students should be assisted to elaborate their own worldviews for their specific careers and professional practices. Then they will be able to live and act as Christians whilst practising their careers.

\section{Methodology of the educational endeavour}

The 2000 declaration of IAPCHE on CHE defines 'methodology of the educational behaviour' as follows:

CHE encompasses all educational endeavours at tertiary or undergraduate and graduate level, in which all facets of created reality, especially human life, are explored and examined in an advanced and more detailed manner than they are in primary and secondary education. (Hulst 2008:32)

The core business of $\mathrm{CHE}$ is education. One of the founding members of IAPCHE, Bennie van der Walt, defines education as the purposeful effort of the educator to guide the student toward maturity and equipment for his/her life task according to specific norms' (Van der Walt 1992:83). Although this definition was formulated towards the end of the previous century, I believe it is just as valid today and deserves more reflection. I will elaborate on a few of the concepts in this definition.

The first is 'purposeful effort of the educator'. This implies that lecturers should be people who are united in their vision of what they want to attain in the lives of their students. The word 'effort' underscores the fact that teaching is not an easy task. It requires committed, passionate lecturers who are willing to make sacrifices for their students. 'Maturity and equipment for life tasks' clearly shows the objective of the $\mathrm{CHE}$ process. It requires of lecturers to guide their students to attain spiritual, emotional and professional maturity so that they are equipped to perform their profession and calling in life. Students need faith, hope and love for God, and love for the neighbour. They need a willingness to deny themselves, to sacrifice and to serve. Students will then be able to live up to a holistic Christianity in all spheres of life. They will be critically and constructively involved in the political, economic, social, judicial, scientific and educational areas of life (Theron \& Lotter 2009:488; Coletto 2010:9). Africa needs these kinds of professionals.

In Van der Walt's definition, 'according to specific norms' indicate that the teaching process should occur in a controlled environment and a planned manner, according to predetermined guidelines, so that the defined objectives could be achieved. This will ensure that the Christian approach will be visible in the manner of teaching and in other academic activities. As Jochemsen (2011:2) states, the moral and spiritual attitude of professionals (lecturers) cannot be separated from their professional practice (teaching and education). The narratives of the students also mention the importance of the educational practice - they value the discussions about the content of their studies, as such discussions facilitate the process of applying the material in their lives. The attitudes and convictions of the lectures are of utmost importance. The narratives cited earlier show the appreciation of the students for the support, encouragement and unconditional acceptance that they received from their fellow-students and lecturers. At Hefsiba ISC, through positive and negative experiences, it is obvious that the success of $\mathrm{CHE}$ in the formation of students is greatly influenced by the methodology of the educational endeavour. 


\section{Conclusion}

Efforts to bring about change in society should be focused on young people, as they are the leaders of the future. Abraham Kuyper is considered the father of Christian higher education. It was his conviction that everything belongs to Christ. Christian academics should develop and exhibit a Christian perspective on, and an integral approach to all subjects in the curriculums essential for students to become Christian professionals in a postmodern pluralistic society. Through CHE, students' faith and education could be integrated in such a way that they would be competent in their profession, but also committed to apply their competency to address the spiritual and material conditions of their continent. Once they are morally transformed, they are equipped to contribute constructively to the transformation of the societies in which they will find themselves. This process could be enhanced by the inclusion of Christian ethics, Christian values and a Christian worldview in the curriculum, and by applying the correct methodology in the educational endeavour. The narratives of three Mozambican students bear witness to the impact that CHE had on their lives, their families, their professional lives and the community in which they live.

\section{Acknowledgements}

The author would like to thank Chipapata, Fátima and Jacinto for their willingness to share their narratives regarding the impact that CHE had on their lives.

\section{Competing interests}

The author declares that she has no financial or personal relationship(s) which may have inappropriately influenced her in writing this article.

\section{References}

Blokhuis, P., 2011, 'The personal character of worldview and its meaning for professional practices', in B. De Muynck, J. Hegeman \& P. Vos, P. (eds.), Bridging the gap: Connecting Christian faith and professional practice, pp. 109-115, Dordt College Press, Sioux Centre.

Brunsdon, A.R. \& Lotter, G.A., 2011, 'Outo-etnografie as selfhulp vir predikante met bedieningsmoegheid: Verkennende opmerkings', Verbum et Ecclesia 32(1), pp. 465-467. http://dx.doi.org/10.4102/ve.v32i1.465

Bull, M.J. \& Newell, J.M., 2003, 'Conclusion: Political corruption in contemporary democracies', in M.J. Bull \& J.M. Newell (eds.), Corruption in contemporary politics, pp. 234-247, Palgrave Macmillan, New York.

Carpenter, J., 2008, 'Christian higher education as a worldwide movement', in N. Lantinga, (ed.), Christian higher education in the global context: Implications for curriculum, pedagogy and administration, pp. 337-352, Dordt College Press, Sioux Centre.

Carpenter, J.A., 2012, 'New Christian universities and the conversion of cultures', in IAPCHE, viewed 19 April 2012, from http://iapche.org/wordpress/?page_id=413

Chaplin, J., 2011, 'Integrity in solidarity: Christian professionals in a plural public sphere', in B. De Muynck, J. Hegeman \& P. Vos (eds.), Bridging the gap: connecting Christian faith and professional practice, pp. 13-24, Dordt College Press, Sioux Centre.

Christian Classics Ethereal Library, n.d., Biography of Abraham Kuyper, viewed 10 October 2012, from http://www.ccel.org/ccel/kuyper

Coletto, R., 2010, 'Reformational institutions for higher education', Word and action 50(413), 9-14.

Daystar University, 2012, Mission and vision, viewed 19 April 2012, from http://www. daystar.ac.ke/index.php?option=com_content\&view=article\&id=177\&Itemid=489

De Klerk, J., 2003, 'Die wetenskap “in u lig” - wat sê dit vir die PUK self?', Koers 68(2\&3), 311-321. http://dx.doi.org/10.4102/koers.v68i2\&3.341

De Muynck, B., Hegeman, J. \& Vos, P., 2011,'Introduction', in B. De Muynck, J. Hegeman \& P. Vos (eds.), Bridging the gap: connecting Christian faith and professional practice, pp. 5-10, Dordt College Press, Sioux Centre.

Du Preez, K.P., 2012, email, 14 May 2012, krugerdup@gmail.com

Eloff, T., 2003, 'Die "nuwe" PUK - verandering én tevredenheid', Word and Action $43(386), 1-3$.
Garber, S., 1996, The fabric of faithfulness, Intervarsity Press, Downers Grove.

Hegeman, J. \& Jochemsen, H., 2011, Direction discernment and moral formation in higher education, in B. De Muynck, J. Hegeman \& P. Vos (eds.), Bridging the gap: Connecting Christian faith and professional practice, pp. 93-108, Dordt College Press, Sioux Centre.

Hittenberger, J.S., 2004, 'Globalization, "marketization", and the mission of pentecostal higher education in Africa', PNEUMA: The Journal of the Society for Pentecostal Studies 26(2), 182-215

Holmes, A.F., 2001, Building the Christian academy, William B. Eerdmans Publishing, Grand Rapids.

Holthaus, S., 2011, 'The gap: An analysis of the present situation in a pluralistic and postmodern society', in B. De Muynck, J. Hegeman \& P. Vos (eds.), Bridging the gap: Connecting Christian faith and professional practice, pp. 39-47, Dordt College Press, Sioux Centre.

Hulst, J.B., 1992, 'Contemporary issues in Christian Higher Education', Wetenskaplike bydraes vir die PU vir CHO: Instituut vir Reformatoriese Studie, series F1 (296-300), pp. 1-8, Institute for Reformational Studies, Potchefstroom.

Hulst, J.B., 2002, 'Introduction', Christian Higher Education 1(2\&3), 119-122.

Hulst, J.B., 2008, 'Highlights of IAPCHE's history', in N. Lantinga (ed.), Christian higher education in the global context: implications for curriculum, pedagogy and administration, pp. 21-32, Dordt College Press, Sioux Centre.

Jochemsen, H., 2011, 'Preface', in B. De Muynck, J. Hegeman \& P. Vos (eds.), Bridging the gap: connecting Christian faith and professional practice, pp. 1-3, Dordt the gap: connecting Christian
College Press, Sioux Centre.

Labuschagne, J.N.R., 2008, 'Die ander vrou - 'n Outo-etnografiese studie van die beroepsbelewenis van ' $\mathrm{n}$ predikant', PhD-tesis, Universiteit van Johannesburg, Johannesburg.

Lategan, L.O.K., 2003, 'The free-wheeling society: what values should be on the agenda and the role of the Christian education in the promotion of these values', Nederduitse Gereformeerde Teologiese Tydskrif 44(3\&4), September \& December, 361-367.

Nguru, F.W., 2008, 'What can Christian higher education do to promote educational well-being in Africa?', in N. Lantinga (ed.), Christian higher education in the global context: implications for curriculum, pedagogy and administration, pp. 135-149, Dordt College Press, Sioux Centre.

Noebel, D.A., 2001, The battle for truth, Harvest House Publishers, Eugene.

North-West University, n.d.(a), Statement about Ethics for a follow-up evaluation or study/research, viewed n.d., from http://www.nwu.ac.za/webfm_send/58853

North-West University, n.d.(b), Rules of the Research Ethics Committee, viewed n.d. from http://www.nwu.ac.za/webfm send/24743, viewed 19 April 2012, from http://www9.georgetown.edu/faculty/jod/augustine/

O'Regan, K., 2012, 'Stamping out corruption is everybody's business', Sunday Times, 29 January, 2012, p. 6.

Pidd, H., 2012, 'German president resigns and could face prosecution in corruption scandal', in The Guardian, viewed 17 February 2012, from www.guardian.co.uk/ world/2012/feb/17/german-president-christian-wullf-resigns1?newsfeed=true

Reason, P. \& Bradbury, H. (eds.), 2008, The Sage handbook of action research participative inquiry and practice, 2 nd edn., SAGE Publications, London.

Theron, P.M. \& Lotter, G.A., 2009, 'The necessity of an integral Christian worldview: reconnoitring the challenges for influencing the unbelieving world', Koers 74(3), 467-493. http://dx.doi.org/10.4102/koers.v74i3.134

Van den Heever, J.A., 2012, Out of Africa there is always something new, viewed 19 April 2012, from http://academic.sun.ac.za/botzoo/paleo/africa.htm

Van der Walt, B.J., 1992, 'A Christian worldview and Christian Higher Education for Africa', Institute for Reformational Studies, Potchefstroom

Van der Walt, B.J. 2008a, 'Transformed by the renewing of your mind: the challenge of Christian Higher Education on the African continent in the twenty-first century', in B.J. van der Walt, Transformed by the renewing of your mind, pp. 93-129, The Institute for Contemporary Christianity in Africa, Potchefstroom.

Van der Walt, B.J., 2008b, 'Our past heritage, present opportunity and future challenge: reflections at the commemoration of the 25th anniversary of the International Association for the Promotion of Christian Higher Education', in B.J. van der Walt, Transformed by the renewing of your mind, pp. 184-198, The Institute for Contemporary Christianity in Africa, Potchefstroom.

Van der Walt, B.J., 2010a, 'Wêreldwye Belangstelling in Christelike Wetenskapsbeoefening en Christelike Hoër Onderwys: hoe Afrika daarby kan baat', Tydskrif vir Christelike Wetenskap (1\&2), 111-132.

Van der Walt, B.J., 2010b, The eye is the lamp of the body: worldviews and their impact, The Institute for Contemporary Christianity in Africa, Potchefstroom.

Van Eeden, E.S., 2006a, 'Die "stem van Potchefstroom" in die samelewing', in E.S Van Eeden (ed.), 'In u lig': Die PU vir CHO, bl. 485-521, Noordwes-Universiteit, Potchefstroom.

Van Eeden, E.S., 2006b, "n Historiese perspektief op die realisering van " $\mathrm{CHO}$ " van die PUK as 'n stem uit Potchefstroom tot 2003', Tydskrif vir Christelike Wetenskap (4), 113-137.

Vorster, J.M., 2007, 'Christian attitude in the South African liberal democracy', Potchefstroom Theological Publications, Potchefstroom.

Vorster, J.M., 2010, 'An ecclesiological model for the ministry of reconciliation in a socio-political context', In die Skriflig 44(2), 429-454. http://dx.doi.org/10.4102/ ids.v44i2.154

Vorster, J.M., 2012, 'Reformational theology in a post-secular era, research discussion group of the Unit for Reforemed Theology, Faculty of Theology, Potchefstroom on 01 March 2012 .

Vos, P., 2011, 'After duty: The need for virtue ethics in moral formation', in B. De Muynck, J. Hegeman \& P. Vos, P. (eds.), Bridging the gap: Connecting Christian faith and professional practice, pp. 143-157, Dordt College Press, Sioux Centre.

Walton, J.H., 2001, The NIV application commentary: Genesis, Zondervan, Grand Rapids. 